\section{Correspondence}

https://doi.org/10.11646/zootaxa.4571.2.13

\title{
Making Louis Agassiz's wish come true: combining forces and a new protocol for collecting comparative skeletal material of sharks, skates and rays, as a comment and an addition to 'The need of providing tooth morphology in descriptions of extant elasmobranch species' by Guinot et al. (2018)
}

\author{
FREDERIK H. MOLLEN \\ Elasmobranch Research, Rehaegenstraat 4, 2820 Bonheiden, BELGIUM. E-mail: frederik.mollen@gmail.com
}

Palaeoichthyologist G. Guinot and colleagues (Guinot et al., 2018) are correct to request that new species descriptions of extant sharks, skates and rays include information on tooth morphology. But, even if their request is heeded, it will not address the broader issue associated with taxa that have been poorly described or incompletely illustrated in the past.

In my opinion, non-type material can contribute to redressing the problems that are associated with incomplete information on tooth morphology where type material is lacking, difficult to access, or insufficient to document sexual, ontogenetic, regional and seasonal heterodonty, where such exists. Such complementary approaches can benefit from contributions from scientists (not only alpha taxonomists [neontologists]) who have access to fresh material. Unfortunately, much of the non-type material that has been collected and illustrated in the past either lacks appropriate documentation or is misidentified. This is especially problematic in those cases where teeth or jaws may be confused with sibling/sympatric species, with species complexes that have been subdivided or with taxa that have been resurrected from synonymy in more recent times. Examples are manifold; below two are picked out, i.e. the bramble shark Echinorhinus brucus (Bonnaterre, 1788) and the common stingray Dasyatis pastinaca (Linnaeus, 1758), as illustrated in Herman et al. $(1989,1998)$. In fact, I am of the opinion that the problem is even more severe than presented by Guinot $e t$ al. (2018).

This letter serves as a plea to combine forces between neontologists and palaeontologists in order to focus on both type and non-type material. It includes guidelines for collecting comparative skeletal material in sharks, skates and rays, with special emphasis on teeth. Finally, this note reflects on the dissemination of (un)published material and data, including over a thousand well-documented jaws in the collections of Elasmobranch Research Belgium (ERB). With more forces combined and better sharing of specimens and data, the research community will certainly be able to meet the goals set.

In fact, it was the Swiss-American palaeontologist and neontologist Louis Agassiz (1807-1873) who already acted accordingly in his elasmobranch studies. In his landmark contribution 'Recherches sur les poissons fossiles', Agassiz (1833-1845, pls A-J) provided detailed comparisons of teeth of extinct and extant ones. Although the latter lacked basic data such as sex and total length, Agassiz was fully aware of this shortcoming. On October 18, 1871, the ever-collecting and exchanging Agassiz (Founder and Director of the Museum of Comparative Zoology at Harvard, Cambridge, Massachusetts) wrote once again to his colleague Spencer Fullerton Baird (Secretary of the Smithsonian Institution, Washington D.C.):

'Do not forget also the jaws of sharks \& skates of which you promised me labelled specimens. My jaws of these families are not identified with precision, having mostly been procured by themselves, without an opportunity of seeing the whole fish. Very truly yours L Agassiz' (see Herber, 1963, pp. 205-206; Fig. 1).

More than any other scientist of his time, Agassiz was aware of the fact that comparative zoology did not only come with a researcher's skills to observe and measure, but also with the quality of the data/collection that served as comparative material.

Case 1-For the dentition of the bramble shark Echinorhinus brucus, Herman et al. (1989, text-pl. 1, pl. 1) illustrated two females (depository not indicated), one of $228 \mathrm{~cm} \mathrm{TL}$, caught off Senegal, the other of $240 \mathrm{~cm}$ TL, caught off the Belgian North Sea coast. However, only a single specimen is known to have been caught in the North Sea and brought on land in Belgium, namely a male of about $175 \mathrm{~cm}$ TL, from the Ostend fish market (see Van Beneden, 1894; registration ERB 1080), the dental morphology of which does not match the one illustrated by Herman et al. (1989). 
In my opinion, the teeth illustrated in these two plates originate from a single set of jaws (i.e., ex Cadenat Collection, R. 397), which is unique in having an aberrant tooth morphology in the $10^{\text {th }}$ file of the left upper jaws. This was once in the private collections of J. Herman, and has now been deposited in the ERB collections. This view has been confirmed by Herman's personal archives of his series, entitled 'Odontologie des Elasmobranches actuels (don. Jacques Herman \& France Ladeuze)', a life achievement which is the result of his personal motto:

'Wishes of the paleontologists-After the capture of these fresh specimens, please do not forget to realize SEM photographs of, at least, their teeth' (Herman \& Van Waes, 2015: 31).

It includes 41 ring folders with original SEM micrographs and annotations, now housed in the special library at ERB. The jaws, together with the original label, provide data on its capture, i.e., off Kayar, Senegal (1958), but not on the entire animal itself, such as sex or length. This supports that the fish-related data as presented by Herman et al. (1989, text-pl. 1, pl. 1) are not based on facts, but rather result from their 'expert judgement' based on the general size of the jaws and tooth shape, or an erroneous link to a specimen recorded by Cadenat \& Blache (1981, p. 25, i.e., a female of 228 $\mathrm{cm}$ TL, Ivory Coast), ignoring its location of capture. The species name, plus the symbol $q$, are now present (in Herman's handwriting) on the lower jaws of R. 397, but these were added at a later date (pers. obs.). The same applies to the seven isolated, gold-coated teeth used for SEM imaging that were labelled ' $+2 m 30$ ', that are now also in the ERB collections. More recently, these teeth were re-illustrated by Herman \& Van Waes (2014, pl. 15), this time said to originate from the year 1852. Although this erroneous date has no consequences for interpreting heterodonty patterns, such record might be problematic for other disciplines (e.g., marine historical ecology). A tooth of the same specimen (R. 397) was probably used again to illustrate vascularisation in E. brucus (see Hovestadt \& Hovestadt-Euler, 1993; Herman et al., 2003), but this now lacks any data.

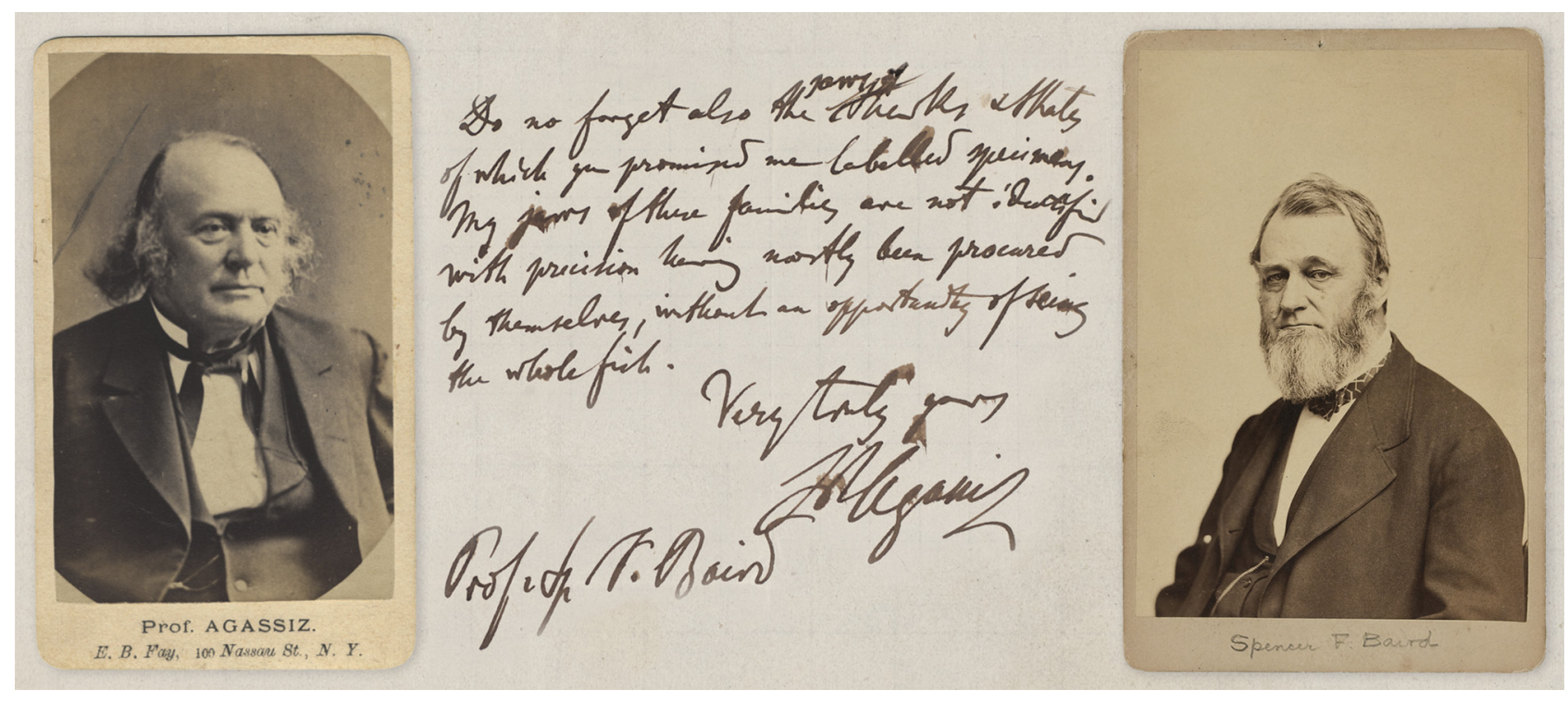

FIGURE 1. Extract of a letter by Louis Agassiz to Spencer Fullerton Baird, October 18th, 1871 (Image \#SIA2019-000779), courtesy of the Smithsonian Institution Archives (centre); 'Carte de visite' of L. Agassiz by E.B. Fay (c. 1870), courtesy of ERB Library (left); Cabinet card portrait (reversed) of S.F. Baird by H. Ulke (1878), courtesy of Swann Auction Galleries, sale 2344, lot 234 (right).

Case 2-For the dentition of the common stingray Dasyatis pastinaca, Herman et al. (1998, pls 4-7) illustrated a female of $80 \mathrm{~cm} \mathrm{DW}$, and a male of $54 \mathrm{~cm}$ DW, both caught in the River Oosterschelde (Eastern Scheldt), southern North Sea, that have reticulated (not smooth) labial (i.e., outer) crown surfaces. However, in view of recent advances in dasyatid taxonomy (see Last et al., 2016a) their identification needs to be reinvestigated, because the genus has been subdivided, with only five (out of 38) species left in Dasyatis (see Compagno, 2005), including D. tortonesei Capapé, 1975. The latter has long been considered to be a junior synonym of the type species, D. pastinaca (see e.g., Ebert \& Stehmann, 2013) and its validity has only recently been accepted (see Iglésias, 2012; Saadaoui et al., 2016; Weigmann, 2016). The geographical distribution of these sibling species overlaps extensively in the Mediterranean, as well as in the northeast Atlantic (Last et al., 2016b; F. Mollen, unpubl. data).

The original description of D. tortonesei was not straightforward (see Séret \& McEachran, 1986) and includes three subsequent steps (Capapé, 1974, 1975, 1977), the first being an unpublished PhD thesis, the second a published paper that makes the name available according to ICZN rules and includes the drawing of a female specimen ( $36 \mathrm{~cm}$ DW and $58 \mathrm{~cm} \mathrm{DL}$ ), and the third step a more detailed morphological description including the designation of a 'holotype' i.e., 
MNHN 1977-0107, an immature male, $520 \mathrm{~mm}$ TL, $275 \mathrm{~mm}$ DW. However, according to the ICZN (art. 73.1), the specimen illustrated in the 1975 contribution should be retained as holotype, rather than the one designated as such in 1977.

Overall, $D$. tortonesei differs only slightly from $D$. pastinaca, mainly by a combination of aspects of morphometry and colouration (see Capapé, 1974, 1975, 1977; dental morphology not provided), so that checking original identifications has proved difficult, if not impossible, for teeth and/or jaws whose voucher specimens have not preserved, nor well documented. In addition, fixation in formalin hampered DNA barcoding, until further research (Saadaoui et al., 2016; F. Mollen, unpubl. data) has shown that the dentition of both species is highly distinct, having reticulated $v s$ smooth crown surfaces. In the absence of a holotype or lectotype for D. pastinaca, Capapé $(1974,1975,1977)$ was clear in his choice which species to retain as type species of the genus ( $c f$. smooth teeth, i.e., D. pastinaca) and which species to erect as new ( $c f$. reticulated teeth, i.e., D. tortonesei), even though some taxonomists would probably have preferred the reverse, but this is beyond the scope of the present contribution. As a result, the teeth illustrated by Herman et al. (1998) should be assigned to D. tortonesei, rather than to D. pastinaca.

These two cases are not listed here to question the merits of Herman's series, but rather to illustrate the problems that are referred to in the introduction. Since Agassiz (1871, see quote above), species identification, doubtful data, lack of data, or even erroneous data, have remained a major concern in numerous comparative studies of the dental morphology of sharks, skates and rays. If not dealt with properly, collecting efforts can lead to misleading conclusions on dental morphology.

A new protocol - In order to study heterodonty in a specific taxon, a large number of specimens, both males and females, of all ontogenetic stages, collected in different regions or even seasons are required. As suggested above, nontype material can be very useful as well, if properly documented. In view of the fact that many sharks, skates and rays attain large sizes, it is often not possible to collect and preserve entire specimens. Curators are not really eager to include large series of non-type material in collections under their care, especially when skeletal material has been separated, leaving the voucher specimen damaged. To tackle these problems, I propose a new protocol for collecting comparative skeletal material.

The protocol (see Fig. 2) starts with verifying sex and taking basic measurements, comprising at least total length (TL) and also disc width (DW) for skates and rays, and noting position and date of capture. Measurements are taken in a straight line, with the specimen lying in its natural position. Each specimen should be photographed in lateral, dorsal and ventral views, including details of the most diagnostic regions such as the underside of the head, to illustrate the position of the mouth and nostrils. Fins and other body parts should be positioned to reflect their natural orientation as closely as possible. Specimens should be cleaned, removing sediment and soiled mucus prior to photography, to ensure that dermal denticles and colour patterns are visible. If possible, a plain homogeneous background is recommended. A scale bar (ruler) and field number should be visible in each photograph. The assigned field tag should never be removed from the specimen until it is ready and finally labelled for transfer to comparative collections. When skeletal elements are removed for preparation, tissue samples should be taken and stored either in $+95 \%$ ethanol and kept refrigerated or immediately deep frozen at $-20^{\circ} \mathrm{C}$, to check the identification of specimens on a molecular level subsequently. Individual teeth can be removed from the jaws and separately labelled for SEM photography, but in all other cases, they should be left in their original positions on the jaws such that information on their exact position and tooth count is preserved.

This protocol minimises the risk of errors and makes it possible to double check basic data easily and to reinvestigate their original identification whenever needed, even many years later. This protocol has been followed by ERB since the year 2000, except for fresh-tissue sampling which did not start systematically until mid 2007, resulting now in more than a thousand well-documented shark, skate and ray jaws, inclusive of over 11,000 digital photographs and even more analogue ones. These represent 47 families, 111 genera and 249 species. In the ERB collections, jaws have not been treated with formaldehyde or hydrogen peroxide, so that dry tissue sampling and DNA barcoding remain possible after preparation, even for those specimens of which fresh tissue was not sampled. However, the success rate of DNA barcoding on such dried jaws depends on the gene used (mtDNA COI > NADH2; F. Mollen, unpubl. data). After sampling of the jaws and possible other skeletal elements, the remaining vouchers are presented to the IRScNB (Brussels), where it is decided whether or not the voucher is retained as is (in liquid), or after complete preparation of remaining skeletal elements such as neurocrania, hyoid arches, pectoral and girdles and/or vertebrae. Each field label is prepared in three copies; the first for the jaws, the second for the voucher specimen and a third if other skeletal remains (e.g., dorsal fin spines) are sampled and prepared separately. For each specimen, digital, but also analogue duplicate records are kept, so to avoid loss of data in the long term, due to technical problems or just because of physical separation of the digital data on the one hand and the collection on the other. Analogue records accompany the comparative collections at all time. 
Dissemination of data-Herman \& Ladeuze's archives 'Odontologie des Elasmobranches actuels', include SEM photographs of several specimens and taxa that have not been published to date. All 41 ring folders (with the exception of the one on Dasyatidae that is missing) have been digitalised by ERB, having been made available by J. Herman to https://shark-references.com/ (Pollerspöck \& Staube, 2018). Many of these are now present on the species-specific pages of this online data platform on living and fossil chondrichthyan fishes. For specimens in the ERB collections that have followed the protocol described here, photographs of the entire fish are being transferred step by step to the same platform and will be made available to the same species-specific pages. Tissue samples are shared with the research community, e.g., for the Chondrichthyan Tree of Life Project. For dental morphology, researchers may request a complete list of specimens and study comparative jaws collections held at ERB.
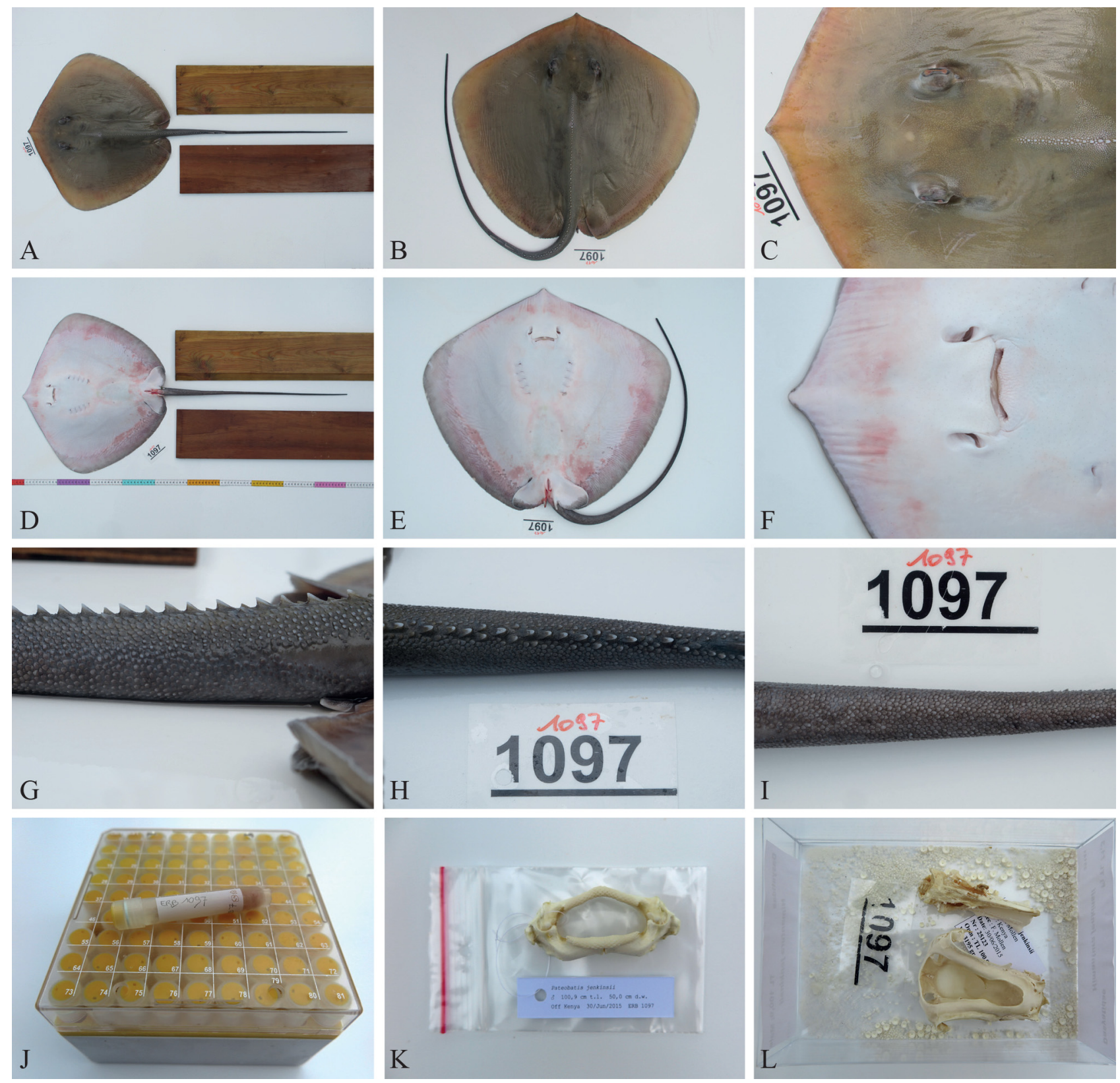

FIGURE 2. Pateobatis jenkensii (Annandale, 1909), ERB 1097, male, $50.0 \mathrm{~cm} \mathrm{DW,} 100.9 \mathrm{~cm}$ TL, caught off Kenya, illustrating a new protocol for collecting comparative skeletal material in sharks, skates and rays which includes photography (A-I), tissue sampling $(\mathbf{J})$ and preservation of jaws at Elasmobranch Research Belgium (K); remaining voucher deposited and skeletonised at the Institut royal des Sciences naturelles de Belgique (L).

In addition to dental morphology, Guinot et al. (2018) suggested (in brackets below) that their plea also concerned other skeletal material, including endoskeletal parts (e.g. neurocranium). This cannot be stressed often enough and it explains why I propose to retain as many skeletal parts as possible, or to make the remaining vouchers available to other 
researchers, if not accepted by museum curators (e.g., through platforms such as Otlet). For specific specimens belonging to the orders Lamniformes, Squatiniformes and Pristiophoriformes in ERB collections, entire specimens, heads or smaller portions of anatomy were CT scanned when still fresh, courtesy of F. Hilte and J. Bauwens, ZNA hospitals, Antwerp (see Mollen et al., 2012, 2016). Several of these files have now been made available online to the research community (see Kamminga et al., 2017).

Even when good data are published, cross-referencing between neontologists and palaeontologists still needs to be promoted. In the past, studies by palaeontologists that included comparative material of extant taxa, often remained unknown or were not included in taxonomic studies by neontologists, and vice versa, although the situation has much improved in more recent years. Let us combine forces and make Louis Agassiz's wish come true.

\section{Acknowledgements}

This note is dedicated to Jacques Herman (Beigem), Dirk C. Hovestadt and the late Maria Hovestadt-Euler (Terneuzen) for sharing their enthusiasm in collecting fresh material and studying dental morphology, comparing fossil and Recent taxa, with so many colleagues and friends, both alpha taxonomists and others, either institution based or independent. I wish to thank Arie de Jong and Jeffrey de Pauw (de Jong Marinelife, Lingewaal), Alexandra Nelson (Swann Auction Galleries, New York), Deborah Shapiro and Heidi Stover (SI Archives, Washington D.C.), Sean Van Sommeran (PSRF, Moss Landing) and Wim Wouters (IRScNB, Brussels) for all kinds of logistic support to ERB collections and library; John W.M. Jagt (Natuurhistorisch Museum, Maastricht), Gavin Naylor (FPSR/FMNH, Gainesville), William White (CSIRO, Hobart) and Marcelo R. de Carvalho (Editor) for critical reading of an earlier version of the typescript and suggesting linguistic/editorial improvements.

\section{References}

Agassiz, L. (1833-1845) Recherches sur les poissons fossiles, planches, 3. Minsinger, Munich, 83 pls.

Agassiz, L. (1871) ALS to S.F. Baird (Cambridge, USA, October 18th, 1871), Smithsonian Institute Archives, Washington D.C., Spencer Fullerton Baird Papers (1833-1889), record unit 7002, series 3, box 13, folder 14.

Cadenat, J. \& Blache, J. (1981) Requins de Méditerranée et de l'Atlantique (plus particulièrement de la Côte Occidentale d'Afrique), In: Faune Tropicale, 21. ORSTOM, Paris, 330 pp.

Capapé, C. (1974) Systématique, écologie et biologie de la reproduction des sélaciens des côtes tunisiennes. PhD thesis, Université de Paris VI, France.

Capapé, C. (1975) Sélaciens nouveaux et rares le long des côtes tunisiennes. Premières observations biologiques. Archives de l'Institut Pasteur de Tunis, 52 (1-2), 107-128.

Capapé, C. (1977) Les espèces du genre Dasyatis Rafinesque, 1810 (Pisces, Rajiformes) des côtes tunisiennes. Cybium, (3) 2, 75 -105.

Compagno, L.J.V. (2005) Checklist of living Chondrichthyes. In: Hamlett, W.C. (Ed.), Reproductive biology and phylogeny of Chondrichthyes. Sharks, batoids and chimaeras. Science Publishers, Enfield/Plymouth, pp. 503-548.

Ebert, D.A. \& Stehmann, M.F.W. (2013) Sharks, batoids and chimaeras of the North Atlantic. FAO Species Catalogue for Fishery Purposes, 7, 523 pp.

Guinot, G., Adnet, S., Shimada, K., Underwood, C.J., Siversson, M., Ward, D.J., Kriwet, J. \& Cappetta, H. (2018) On the need of providing tooth morphology in descriptions of extant elasmobranch species. Zootaxa, 4461 (1), 118-126. https://doi.org/10.11646/zootaxa.4461.1.8

Herber, E.C. (1963) Correspondence between Spencer Fullerton Baird and Louis Agassiz-Two pioneer American naturalists. Smithsonian Institution, Washington D.C., 237 pp.

Herman, J., Hovestadt-Euler, M. \& Hovestadt, D.C. (1989) Part A: Selachii. No. 3: Order: Squaliformes—Families: Echinorhinidae, Oxynotidae and Squalidae. In: Stehmann, M. (Ed.), Contributions to the study of the comparative morphology of teeth and other relevant ichthyodorulites in living supraspecific taxa of chondrichthyan fishes. Bulletin de l'Insitut royal des Sciences naturelles de Belgique, Biologie, 59, 101-157.

Herman, J., Hovestadt-Euler, M., Hovestadt, D.C. \& Stehmann, M. (1998) Part B: Batomorphii 4a: Order Rajiformes—Suborder Myliobatoidei-Superfamily Dasyatoidea-Family Dasyatidae-Subfamily Dasyatinae-Genera: Amphotistius, Dasyatis, Himantura, Pastinachus, Pteroplatytrygon, Taeniura, Urogymnus and Urolophoides (incl. supraspecific taxa of uncertain status and validity), Superfamily Myliobatoidea-Family Gymnuridae-Genera: Aetoplatea and Gymnura, Superfamily Plesiobatoidea-Family Hexatrygonidae-Genus: Hexatrygon. In: Stehmann, M. (Ed.), Contributions to the study of the comparative morphology of teeth and other relevant ichthyodorulites in living supra-specific taxa of chondrichthyan fishes. Bulletin de l'Insitut royal des Sciences naturelles de Belgique, Biologie, 68, 145-197.

Herman, J., Hovestadt-Euler, M. \& Hovestadt, D.C. (2003) Part A: Selachii. Addendum to 1: Order Hexanchiformes-Family Hexanchidae, 2: Order Carcharhiniformes, 2a: Family Triakidae, 2b: Family Scyliorhinidae, 2c: Family Carcharhinidae, Hemigaleidae, Leptochariidae, Sphyrnidae, Proscylliidae and Pseudotriakidae, 3: Order Squaliformes: Family Echinorhinidae, Oxynotidae and Squalidae. Tooth vascularisation and phylogenetic interpretations. In: Stehmann, M. (Ed.), Contributions to the study of the comparative morphology of teeth and other relevant ichthyodorulites in living supraspecific taxa of chondrichthyan fishes. Bulletin de l'Insitut royal des Sciences naturelles de Belgique, Biologie, 73, 5-26. 
Herman, J. \& Ladeuze, F. (n.d.) Odontologie des Elasmobranches actuels. Elasmobranch Research Belgium Archives, Bonheiden, ring folders $1-41$.

Herman, J. \& Van Waes, H. (2014) Observations concerning the evolution and the parasystematics of all the living and fossil Chlamydoselachiformes, Squatiniformes, Orectolobiformes, and Pristiophoriformes, based on both biological and odontological data. Suggestion of a possible origin of the order Pristiophoriformes, of the order Ganopristiformes and a global synthesis of the previous systematic proposals. Géominpal Belgica, 6, 1-347.

Herman, J. \& Van Waes, H. (2015) Comments and reflections on existing distribution maps. Géominpal Belgica, 6 (addition), 1-31.

Hovestadt, D.C. \& Hovestadt-Euler, M. (1993) The vascularization system in teeth of Selachii. In: Herman, J. \& Van Waes, H. (Eds.), Elasmobranches et Stratigraphie. Belgian Geological Survey, Professional Paper, 264, 241-258.

Iglésias, S.P. (2012) Chondrichthyans from the north-eastern Atlantic and the Mediterranean. A natural classification based on collection specimens, with DNA barcodes and standardized photographs. Provisional version 06 (April 1st, 2012 ), 83 pp. Available from: http://www.mnhn.fr/iccanam (Accession date not recorded). https://doi.org/10.13140/2.1.3801.4245

Kamminga, P., De Bruin, P.W., Geleijns, J. \& Brazeau, M.D. (2017) X-ray computed tomography library of shark anatomy and lower jaws surface models. Scientific Data, 4, 170047. https://doi.org/10.6084/m9.figshare.c.3662366.v1

Last, P.R., Naylor, G.J.P. \& Manjaji-Matsumoto, B.M. (2016a) A revised classification of the family Dasyatidae (Chondrichthyes: Myliobatiformes) based on new morpological and molecular insights. Zootaxa, 4139 (3), 345-368. https://doi.org/10.11646/zootaxa.4139.3.2

Last, P.R., White, W.T., de Carvalho, M.R., Séret, B., Stehmann, M.F.W. \& Naylor, G.J.P. (2016b) Rays of the world. CSIRO Publishing, Clayton South, vii +790 pp.

Mollen, F.H., Wintner, S.P., Iglésias, S.P., Van Sommeran, S.R. \& Jagt, J.W.M. (2012) Comparative morphology of rostral cartilages in extant mackerel sharks (Chondrichthyes, Lamniformes, Lamnidae) using CT scanning. Zootaxa, 3340, $29-43$.

Mollen, F.H., Van Bakel, B.W.M. \& Jagt, J.W.M. (2016) A partial braincase and other skeletal remains of Oligocene angel sharks (Chondrichthyes, Squatiniformes) from northwest Belgium, with comments on squatinoid taxonomy. Contributions to Zoology, 85 (2), 147-171.

Pollerspöck, J. \& Straube, N. (2018) Shark-References, bibliography database of living/fossil sharks, rays and chimaeras (Chondrichthyes: Elasmobranchii, Holocephali), version 2018. Available from: www.shark-references.com (Accessed 23 October 2018).

Saadaoui, A., Saidi, B., Elglid, A., Séret, B. \& Bradai, M. (2016) Taxonomic observations on stingrays of the genus Dasyatis (Chondrichthyes: Dasyatidae) in the Gulf of Gabès (southeastern Mediterranean Sea). Zootaxa, 4173 (2), 101-113. https://doi.org/10.11646/zootaxa.4173.2.1

Séret, B. \& McEachran, J.D. (1986) Catalogue critique des types de poissons du Muséum national d'Histoire naturelle (suite), Poissons batoïdes (Chondrichthyes, Elasmobranchii, Batoidea). Bulletin du Muséum national d'Histoire naturelle, Section AZoologie, Biologie et Écologie animales, 8 (4), Supplement, 3-50.

Van Beneden, E. (1894) Rapport de M. Ed. Van Beneden, premier commissaire. Bulletin de l'Académie royale des Sciences, des Lettres et des Beaux-Arts de Belgique, 3 (27), 870-874.

Weigmann, S. (2016) Annotated checklist of the living sharks, batoids and chimaeras (Chondrichthyes) of the world, with a focus on biogeographical diversity. Journal of Fish Biology, 88 (3), 837-1037.

https://doi.org/10.1111/jfb. 12874 